\title{
A modinha como fenômeno coletivo social sob uma perspectiva andradiana e sua análise poética
}

The modinha as a social collective phenomenon from an Andradian perspective and its poetic analysis

Pedro Razzante Vaccari ${ }^{7}$ Unesp Instituto de Artes pedrovaccari@hotmail.com 


\section{Resumo}

Este artigo tem por objeto principal a análise da modinha enquanto documentação musical para a busca de uma melhor compreensão da sociedade brasileira, com embasamento em Mário de Andrade. Propõe-se, além disso, traçar um paralelo entre essas manifestações do Brasil imperial e a música popular brasileira do século $X X$ e da atualidade, procurando exemplos de compositores e intérpretes que mantiveram a tradição da modinha, de serestas e canções com funções coletivas sociais similares àquela, como o samba-canção da década de 1930. Dessa forma, os resultados foram alcançados por meio de análises de modinhas, relacionando-as com sua contextualização histórica, possibilitando uma sondagem dos grupos sociais que as produziram e a continuidade da tradição na posteridade. A análise poética de "Viola quebrada", de Mário de Andrade, possibilitou situar e contextualizar o estudo sob o prisma etnomusicológico, onde - Brasil pôde ser visto como uma nação que foi apropriada pelos colonizadores, sem considerar suas idiossincrasias naturais, e como essa metáfora é colocada no poema em questão.

Palavras-chave: Modinha; coletivo; cultura brasileira; tradição; Mário de Andrade.

\section{Abstract}

This paper focuses on the analysis of the Brazilian song called Modinha as musical historical research to improve an understanding of Brazilian contemporary society, with the bibliography of Mário de Andrade. It is also aimed to draw a parallel between this music of Imperial Brazil and Brazilian popular music of the twentieth century and the present day, looking for examples of composers and performers who have maintained the tradition of Modinha, and songs with similar social collective functions as the samba-song of the 1930s. In this way, the results were achieved through analyzes poems and lyrics of Modinhas, relating them to their historical contextualization, enabling a survey of the social groups that produced them and the continuity of the tradition in posterity. The analysis of Mário de Andrade's "Viola quebrada" made possible to contextualize the research on Ethnomusicological survey, regarding Brazil as a country that was appropriated by the Portuguese without being considered with its particular features, and how this metaphor is employed poetically.

Keywords: Modinha; collective; Brazilian culture; tradition; Mário de Andrade. 


\section{Introdução}

Este artigo pretendeu investigar quais eram as funções sociais da modinha dentro do panorama histórico do Brasil imperial e qual ou quais estilos composicionais adotaram essas mesmas funções durante o século XX, seus compositores e intérpretes. Que classes sociais essas modinhas representavam? Quais foram os gêneros que continuaram a tradição da modinha e suas funções sociais no Império?

A fim de responder tais questões, recorreu-se a Mário de Andrade (1893-1945), um dos pioneiros a relacionar a música brasileira com a sociedade da qual ela é proveniente, segundo José Bento Faria Ferraz, em Silva (1997).

Além disso, Andrade nos interessa, especialmente, por ter coletado e pesquisado o material de modinhas do século XIX, trabalho que resultou na publicação das Modinhas imperiais (1930).

Mas por que o interesse particular do autor de Macunaíma pela modinha? Provavelmente por ela ser um dos pilares mestres sobre os quais se ergueu todo o arcabouço da música popular brasileira [...], aglutinando outras formas de cantigas e de danças que os colonos traziam [...]", tendo " [...] a virtude de condensar em si, por quase século e meio, o poder criador e a musicalidade da nação que ia crescer e se formar" (ARAÚJO, 1963, p.11). Claro que Mozart de Araújo pertence, junto a Bruno Kiefer, a uma fase positivista e romantizada da historiografia musical brasileira, em que a música é exaltada sem crítica - uma espécie de nacionalismo tardio e folhetinesco. Quando se refere a "arcabouço", portanto, deve ser considerado o contexto da época da publicação - pós-Estado Novo e às vésperas do Golpe Militar de 1964, Mozart de Araújo se utiliza da Modinha como um elemento de afirmação da nacionalidade e identidade cultural, não se atendo a uma escrita científica.

De fato, além de ter se tornado o gênero de canção por excelência de fins do Império, seu papel como transpositora de barreiras sociais, na medida em que disseminava a produção da elite entre as camadas mais baixas da população, formando a partir dessa mistura uma nova espécie de canção, é valioso para a pesquisa da sociedade da época de transição entre a Monarquia e a República. Andrade (1936, p. 5) complementa esse argumento salientando o valor, para as futuras pesquisas, do fenômeno sociocultural da modinha:

Mas a moda se acabou, morta de saciedade, em pleno mel. Era justo que passasse de moda, porém teve significação importante na complexidade musical brasileira e produziu obras gentis. Pelo papel que representou, faz parte imprescindivel dos nossos estudos etnográficos. Pelo que criou de bom, de gracioso e mesmo de lindo, não é justo que permaneça no ostracismo da nossa ignorância atual.

É claro que o ostracismo a que o musicólogo se refere data de 1936, e, obviamente, muita bibliografia a respeito não só de modinhas, mas de pesquisas etnográficas em geral foi despontando ao longo de todos esses anos, e essa situação se transformou pouco a pouco, como atesta Carlini (1994, p.9-10): 
A nova postura de abordagem e pesquisa de manifestações folclóricas, com o objetivo de investigar os elementos formadores da nacionalidade [...], influenciou compositores e pesquisadores de todo o mundo. Este fator também contribuiu para revalorização geral do conceito de Arte e, em plano paralelo, ao incremento das técnicas e da metodologia de coletas etnográficas, particularmente de manifestações musicais folclóricas.

Deve-se ressaltar, no entanto, que há poucos estudos sistemáticos e específicos a respeito do material musical que talvez um dos mais importantes estudiosos da cultura brasileira coletou, organizou e disponibilizou para análise e difusão. Grande parte das obras consultadas para a concepção deste trabalho dissertam a respeito da modinha, suas origens e sua história, mas poucas conseguem traçar um paralelo substancial e sólido entre essas manifestações musicais e o contexto social em que foram produzidas, e seu posterior desenvolvimento dentro da música popular brasileira.

A maioria das pesquisas em música, por outro lado, salienta aspectos puramente técnicos de composições de ordem erudita, não se aprofundando nas suas estruturas enquanto representantes de costumes e práticas de um povo específico, de um determinado período histórico. Como escreve Ikeda (1995, p. 9): "Os estudos musicais determinam-se sobretudo como um ramo da estética, através das descrições, restauros, edições, concertos e gravações de músicas 'clássicas' e não na busca de compreensão da música como fenômeno social".

Há essa preocupação, de fato, em trabalhos mais recentes de historiadores e sociólogos. Um dos autores contemporâneos que buscou tratar a música como fenômeno social foi o inglês Eric Hobsbawm (1996), que, em seu livro História social do jazz, afirma terem sido escassas, até então, as obras e pesquisas que investigassem, do ponto de vista histórico e social, esse estilo de música popular norte-americana do século XX.

Essa situação apresenta-se de modo similar em relação à modinha brasileira. Duas importantes obras que procuraram se aprofundar nos estudos sobre o gênero, $A$ modinha e o lundu no século XVIII, de Mozart de Araújo, e A modinha e o lundu: duas raízes da música popular brasileira, de Kiefer, datam de 1963 e 1986, respectivamente, publicações já antigas em matéria de pesquisas científicas. Além disso, mesmo esses trabalhos parecem tratar superficialmente as raízes da modinha enquanto produto do meio, restringindo-se a descrições de cunho nacionalista, de exaltação e admiração, sem o senso imparcial necessário à produção científica.

Não se encontrou, ainda, bibliografia suficiente sobre as modinhas coletadas nas pesquisas e missões folclóricas pelo país organizadas por Mário de Andrade, a não ser no volume de Modinhas imperiais, publicado em vida, e mesmo na obra A música popular brasileira na vitrola de Mário de Andrade, de Toni (2003), que, embora apresente informações novas relevantes sobre o tema, não se debruça particularmente sobre esse gênero musical.

Este artigo, além do mais, propõe debater questões sobre a modinha hoje. O problema é: qual é a modinha de hoje? Ou melhor, que gênero de música popular da atualidade se aproxima mais da antiga modinha: a canção romântica acompanhada por instrumento de cordas dedilhadas - principalmente o violão, com ornamentação e fi- 
guração musical em grande parte derivadas da ópera italiana do século XVIII? Que grupos ou compositores brasileiros ainda produzem música popular que possam descender, de alguma forma, da modinha?

Alguns compositores da primeira metade do século XX continuaram a tradição da modinha, dentre eles, segundo Tinhorão (1975), Ataulfo Alves e seu samba-canção, Silvio Caldas e Orestes Barbosa com canções como "Chão de estrelas", e, de uma geração mais recente, Chico Buarque de Hollanda. Desse período em diante, no entanto, as inúmeras mudanças quanto à concepção de composição, o aprimoramento das técnicas de gravação e a própria transformação da sociedade, levaram a canção - derivada, dentre outros estilos, da velha modinha - a tomar rumos dos mais variados, que, consequentemente, podem ter mudado sua função social.

Tinhorão (SANCHES, 2004) afirmou que o gênero encerrou sua participação na história da música, e que a tendência geral, com o fim da canção, é que o rap se estabeleça como a nova forma de manifestação musical popular.

O professor e compositor Luiz Tatit (MATHIAS, 2004), por outro lado, avaliou que a tecnologia contribuirá para que a melodia cantada com acompanhamento se desenvolva de outros modos, tornando-se um estilo novo, consonante com a contemporaneidade.

Procurou-se, portanto, também investigar não só o possível substituto da modinha e suas funções sociais, mas também qual estilo do cancioneiro atual parece ser similar, dentro da sociedade, ao fenômeno da modinha, ou que compositores atuam, hoje, como verdadeiros modinheiros do século XXI.

\section{A etnomusicologia em Mário de Andrade}

Na época de Mário de Andrade, os estudos envolvendo a etnografia e o fenômeno do folclore como atividade sociocultural eram ainda bastante rudimentares e inexpressivos. Carecia-se, principalmente, de uma bibliografia sistematizada e organizada, de uma abordagem particular e de incentivos do próprio Estado. Carlini (1994, p.7), avalia que havia um

[...] preconceito comum das classes dominantes frente às manifestações artísticas das camadas subalternas, resultando na ausência de política cultural nacional e a consequente [sic] falta de apoio estatal para o incremento das pesquisas científicas e estudos etnográfico-musicais [...].

As obras capitais que se aprofundaram sobremaneira nos assuntos que concernem à formação da sociedade brasileira, Casa-Grande e Senzala, do sociólogo Gilberto Freyre, e Raízes do Brasil, do historiador Sérgio Buarque de Holanda, datam de 1933 e 1936, respectivamente, sendo que as Modinhas imperiais, de Mário de Andrade, foram publicadas em 1930. Ou seja, até então, pouco ou quase nada havia de material bibliográfico de relevância para que se pudesse empreender projetos específicos sobre o tema da música nacional como produto proveniente do social. 
Em Música, doce música, num texto de 1927, intitulado "Luciano Gallet: canções brasileiras", Andrade (1963, p.171) afirmara:

No Brasil o estudo da música de folclore é duma ausência vergonhosa. O peior é que até documentação do passado falta por tal fórma, que hoje é materialmente impossível a gente fazer um estudo de valor prático sobre o que foi a nossa música popular e como ela evoluiu.

Andrade, no entanto, parece não ter presenciado, infelizmente, o posterior processo de crescimento da etnomusicologia. Sua ambição de divulgar, amplamente, a produção cultural do povo, tornando-a acessível ao maior número possível de indivíduos, não foi realizada durante a sua vida, embora tenha se mostrado presente desde as suas primeiras publicações.

Em uma obra impressa pelo Centro Cultural São Paulo (1992, p.35), apresenta-se o modernista "preocupado com a democratização do saber e o respeito à cultura popular", preocupação essa que se mostra forte desde a Paulicéia desvairada (1921), em que ele reinventa o Hino Nacional Brasileiro no poema "O domador", e emprega versos populares e de carnaval para produzir suas próprias composições. Dissertando sobre a Paulicéia, e fazendo a conexão entre o Mário escritor e musicólogo, Lopez (1972, p.76) afirma que as inserções folclóricas na obra

[...] servem para evidenciar a descoberta do povo, postulada pelas tendências modernistas de então. São o resultado dêsse compromisso amplo e geral (ainda de certa forma afetivo) e do concurso de elementos que o interessado em produção popular descobre no material de estudo do professor de Música do Conservatório Dramático e Musical, cargo que Mário exercia então. Esses elementos são o ritmo e a sonoridade, que servem à sua preocupação em reformular o verso, para criar o verso harmônico.

Porém, o pioneirismo e a originalidade de Mário de Andrade na investigação folclórica talvez residam no fato de ter ele empreendido, além de pesquisas bibliográficas, algumas viagens a regiões do país para coletar o material tradicional do povo acumulado ao longo dos anos. Os resultados de uma dessas viagens, a Missão de Pesquisas Folclóricas de 1938, no Norte e no Nordeste do país, estão sendo mostrados ao público, em exposição permanente, no Centro Cultural São Paulo. Em Cantos populares do Brasil: a missão de Mário de Andrade, publicado pelo Centro Cultural São Paulo (2007, p.4), que foi distribuído aos visitantes da exposição, conta-se um pouco sobre o audacioso evento que foi a Missão:

Depois de viajar por quase 6 meses, a equipe da Missão de Pesquisas Folclóricas regressou a São Paulo antes do previsto, sem saber ao certo qual seria o destino de suas investigações. [...] Mário acompanhou a catalogação e organização do material recolhido: instrumentos musicais, objetos de culto religioso, fotografias, reproduções de desenhos, gravações musicais etc. 
Mais adiante, na mesma publicação, Flavia Camargo Toni nos informa a respeito do papel desempenhado pelo musicólogo, por meio de sua incessante busca, para a história da etnomusicologia.

O interesse do autor de Paulicéia desvairada pela etnomusicologia, porém, aparentemente, partiu, além de sua paixão natural pela cultura nacional, de sua imersão em leituras consagradas do pensamento de finais do século XIX e princípios do século XX.

Em Mário de Andrade: ramais e caminho, Lopez (1972) apresenta um perfil do autor de Modinhas imperiais em que salienta as possíveis influências recebidas, das inúmeras tendências do então nascente século XX, para a concepção da sua abundante e heterogênea obra. Mostra como o escritor, desde os primórdios de sua produção literária e de pesquisas etnográficas, colocara, em primeiro plano, a sua preocupação com a formação de um estilo artístico que, ao mesmo tempo, preservasse e comunicasse o rico material oriundo de manifestações folclóricas, de forma simples e direta. As intenções do musicólogo, conclui-se, eram de utilizar os recursos da linguagem escrita e, também, da partitura para transmitir o legado da tradição oral brasileira de contos, danças e canções, sistematizando esse acervo e tornando-o acessível a qualquer indivíduo, como bem demonstra o acervo da Missão Folclórica em exposição. Ele acreditava, em realidade, ser capaz de recolher essa abundante diversidade de produção cultural e organizá-la, analisá-la e, a partir dela, compor uma obra que tivesse um caráter nitidamente brasileiro.

Dessa forma, podemos afirmar que o idealizador das missões folclóricas, com base na documentação bibliográfica citada acima e na exposição do Centro Cultural São Paulo, foi um dos pioneiros na exploração do Brasil e sua cultura multiétnica, e talvez um dos precursores da atual onda de valorização do popular como representação de uma determinada sociedade.

Seus esforços para efetivar a divulgação e socialização do material folclórico nacional constituem, com certeza, até hoje, um estímulo para os jovens pesquisadores, que ele próprio classificava como os mais capazes de executar as investigações concernentes a esse panorama cultural tão vasto e tão rico.

\section{A modinha}

Da mesma forma que o Brasil Colônia foi obrigado a incorporar as características conflitantes de uma civilização estranha à sua, como Sérgio Buarque de Holanda (1980) argumenta no primeiro parágrafo de Raízes do Brasil - assunto que abordarei melhor na última seção - , a nossa música tem as suas origens principais assentadas na tradição importada da Europa. Como coloca Mário de Andrade (1963, p.21): "A nossa cultura sendo de base integralmente europea, fez com que a nossa música, embora já popularmente possua caracter nacional enorme, se manifestasse em principal sob as normas da criação europea". 
Contribuíram para isso, no entanto, os costumes e as maneiras importadas que foram introduzidas, principalmente, por meio das minorias abastadas, em cujo ambiente nasceu a modinha, que posteriormente se popularizou entre as classes inferiores. Esse argumento é reforçado por Carlini (1994, p.12), que afirma: "Não interessada por obras [...] que aproveitassem melodias populares ou folclóricas, a elite brasileira seguiu ouvindo música européia em acordo com a noção de modernidade e civilidade".

E a modinha se desenvolveu tanto nas ruas como nos salões aristocráticos e nas cortes, adquirindo, a partir daí, uma forma nova e distinta da modinha portuguesa ${ }^{2}$, derivada, sobretudo, da ópera italiana em ascensão no gosto do incipiente público burguês.

Entretanto, foi um homem do povo, o poeta e cantador mulato chamado Domingos Caldas Barbosa (1740-1800), considerado o primeiro compositor popular brasileiro, o responsável pela divulgação da modinha no seio da aristocracia europeia. Segundo o pesquisador e crítico musical José Ramos Tinhorão, em entrevista publicada na Folha de S.Paulo (SANCHES, 2004), Barbosa atuou como um interceptor entre o povo e a elite ao dar conhecimento de um estilo e maneira de tocar e cantar seculares, para as cortes da nobreza, que a elas pareceu revolucionário - acostumadas que estavam apenas às audições de óperas. Além disso, corrobora a conjetura de que a modinha é a primeira forma de canção brasileira.

As origens fundamentalmente negras da modinha são significativas. É de se notar que a influência da África na Península Ibérica, especialmente em Portugal e, consequentemente, no Brasil, acarretaram, com a ajuda do clima propício à languidez e ao ócio dos trópicos, em uma certa predisposição particular da população à desordem e à insubmissão para qualquer tipo de atividade disciplinada. Essas características étnicas herdadas de um outro continente teriam sido responsáveis por uma modorra e moleza tomadas de empréstimo pela colônia de Portugal, ainda jovem, e deixaram profundas marcas na sua estrutura social e cultural. Especificamente sobre a terra lusitana, Gilberto Freyre (1983, p.5), em Casa-Grande e Senzala, disserta:

A singular predisposição do português para a colonização híbrida e escravocrata dos trópicos, explica-a em grande parte o seu passado étnico, ou antes, cultural, de povo indefinido entre a Europa e a África. [...] o ar da África, um ar quente, oleoso, amolecendo nas instituições e nas formas de cultura as durezas germânicas; corrompendo a rigidez moral e doutrinária da Igreja medieval; tirando os ossos ao Cristianismo, ao feudalismo, à arquitetura gótica, à disciplina canônica, ao direito visigótico, ao latim, ao próprio caráter do povo.

Essa ascendência, como não poderia deixar de ser, não afetou menos as práticas culturais e, inclusive, as raízes da então nascente produção musical da colônia. Sobre esse aspecto, Sérgio Buarque de Holanda (1981, p.31) argumenta:

\footnotetext{
2 As modinhas portuguesas, de acordo com Cascudo (2000, p.584), eram entoadas em um canto a duas vozes, e possuíam "[...] linha melódica mais singela, estabilidade tonal e modal maior, [...] privadas daquilo que fazia o encanto das brasileiras e que já era um traço inconfundível de caracterização nacional". Mário de Andrade (1980), inclusive, arrisca uma superioridade da modinha brasileira em relação à portuguesa.
} 
À influência dos negros, não apenas como negros, mas ainda, e sobretudo, como escravos, [...] (a) população não tinha como oferecer obstáculos sérios. Uma suavidade dengosa e açucarada invade, desde cedo, todas as esferas da vida colonial. Nos próprios domínios da arte e da literatura ela encontra meios de exprimir-se, principalmente a partir do Setecentos e do Rococó. O gosto do exótico, da sensualidade brejeira, do chichisbeísmo, dos caprichos sentimentais, parecem fornecer-lhe um providencial terreno de eleição, e permitem que, atravessando o oceano, vá exibir-se em Lisboa, com os lundus e modinhas do mulato Caldas Barbosa [...].

A boa recepção da modinha em Lisboa, portanto, pode ser naturalmente explicável, visto que a sua primitiva "doçura" e a sensualidade quase voluptuosa estivessem em plena consonância com as raízes sobre as quais se assentaram o país de Camões, em grande parte provenientes de influências diretas do continente africano vizinho. Absorvendo essa atmosfera multiétnica e dotado de ousados vanguardismos, o gênero foi apresentado e acolhido pela corte lisboeta.

Em seu livro Pequena história da música popular (1975), Tinhorão descreve a maneira como a modinha foi recebida nas cortes, em seus primórdios, por meio da interpretação carismática e inusitada do trovador Caldas Barbosa. Salienta, em seguida, que documentos de época mostram, claramente, que o novo estilo de composição apresentado pelo mulato para a Rainha D. Maria, na capital portuguesa, "[...] era o rompimento declarado não apenas com as formas antigas de canção, mas com o próprio quadro moral das elites, representado pelas mensagens dos velhos gêneros [...]" (TINHORÃO, 1975, p.11).

E o gênero, apesar de romper, pela suas inovações, com a música que, tradicionalmente, dominara os salões aristocráticos, agradou e se firmou. Araújo (1963) observa, em A modinha e o lundu no século XVIII, que a moda e a modinha foram as práticas que se disseminaram na corte, da mesma forma que a ópera, no teatro, e a chamada Fofa, nas ruas. Ou seja, esse tipo de canção se desenvolveu sob o respaldo da aristocracia lisboeta e logo tornou-se o seu estribilho preferido.

A canção derivada da moda, porém, aparentemente nunca foi apenas música exclusiva dos nobres e se espalhou também pelas ruas e praças do Império. Mendes et al. (1983, p.337) narram a sua trajetória, por diversos anos, até que se firmasse como prática musical popular amplamente divulgada. Nas suas palavras:

Somente no fim do século (XIX) é que a modinha deixaria o piano e passaria ao violão do povo, sob forte influência da valsa. A popularização da modinha deu-se a partir do trabalho dos músicos de teatro de revista que, recriando o gênero, conquistaram um grande público no Rio de Janeiro.

Em seu Dicionário do Folclore Brasileiro, Câmara Cascudo (2000) salienta, no entanto, que as influências advindas do estilo Romântico, então em voga, especialmente por meio da popularização da valsa, transformaram a modinha, tornando-a excessivamente sentimental e modificando-lhe o compasso, de binário, das velhas modinhas, para o ternário, que por sinal é característico da valsa. Afirma, ainda, que as escolhas dos poemas para as composições a partir de então restringiram-se a "Gonçalves Dias, 
Álvares de Azevedo, e Casimiro de Abreu. Não têm conta as modinhas publicadas, na época, com os seus versos" (CASCUDO, 2000, p.584). Um exemplo pode ser encontrado em Que noites eu passo, coletada por Mário de Andrade (1980). A referência ao sabiá, à mata e à natureza como um lugar saudoso, perdido e lembrado com nostalgia pelo poeta é nitidamente uma influência de leituras romanescas europeias. Por sinal, o compasso também é ternário (3/4).

Essa influência levou a um choque natural de estilos, e, embora os compositores procurassem ressaltar, em suas obras, uma autenticidade musical brasileira, a quantidade de elementos estrangeiros na então sentimental modinha eram como que um empecilho para a sua caracterização como produto nacional. Em $A$ modinha e o lundu: duas raízes da música popular brasileira, de Kiefer (1986, p. 23), alguns exemplos demonstram essa tendência nas composições do século XIX:

A análise a que submetemos algumas dezenas de modinhas brasileiras do século passado (XIX) permitiu-nos observar um conflito entre a herança européia (árias de corte cultivadas em Portugal no século XVIII; ópera italiana do século XIX) e a vontade de expressão musical, em termos românticos, do nosso modo de sentir as coisas do amor.

Dessa forma, tecnicamente, como atestam as Modinhas imperiais de Mário de Andrade, algumas obras são, desde Domingos Caldas Barbosa, semelhantes ao bel canto no exagero de ornamentações e exibições de virtuosismo vocal, que acabam comprometendo a sua singeleza, coloca Kiefer (1986). Entretanto, apesar de descender diretamente da ópera italiana, a modinha brasileira do século XIX, lírica, melancólica, geralmente se caracteriza por um estilo mais doce e menos espalhafatoso que o apresentado nas árias que então enfeitiçavam o público europeu e as elites brasileiras. E foi salientando esses elementos, da delicadeza e do suspiro, como bem definiu Mário de Andrade, que o gênero conseguiu, à sua maneira, encontrar a sua "brasilidade".

\section{A modinha no século $X X$}

A modinha, no começo do século XX, assumiu novas formas através da figura de Catulo da Paixão Cearense (1863-1946), compositor que declarava querer fazer uma "reforma" no gênero. Suas inovações foram, porém, transformá-lo em algo que está mais próximo do Romance medieval, devido à utilização de poemas longos e do caráter "menestrel" da sua forma composicional.

Tinhorão (1975) explica, entretanto, que o nome modinha vai gradualmente começando a ser substituído por canção. Isso se dá, em parte, por ter se tornado o nome sinônimo de melodia sentimental, chorosa, e os compositores e executantes passaram a procurar um estilo que não fosse tão restrito e limitado em "lamúrias" e "lamentações". 
Em Toni (2003, p.235) há um manuscrito do próprio Mário de Andrade, feito na capa de um de seus discos, o de Floriano Belham e Grupo do Canhoto entoando "Saudades do meu barracão", de Ataulfo Alves, em que Mário disserta sobre as mudanças que levaram a modinha a se transformar em canção:

Modinha: À medida que esta desaparece ou vive mais desatendida (?) dos seresteiros, vai sendo substituída pelo samba-canção, que é realmente uma modinha nova, de caráter novo, mas canção lírica solista, apenas com uma rítmica fixa de samba, em que porém a agógica já não é mais realmente coreográfica, mas de canção lírica. Ora isso é uma evolução lógica, por assim dizer, fatal. A modinhade-salão passada prá boca do povo popular adotou mesmo ritmos coreográficos, o da valsa e o da chótis principalmente. Ora êstes eram sempre ritmos importados, não da criação imediata nacional. O samba canção é a nacionalização definitiva da modinha. (TONI, 2003, p.235).

\author{
"Saudades do meu barracão"3 \\ Hoje choro com saudade do meu barracão \\ Toda riqueza que havia era um violão \\ E uma morena faceira me desprezou, ô, ô, ô, \\ Só me deixou tristeza a alegria levou. (Ataulfo Alves, 1935).
}

Tinhorão (1975), endossando o argumento acima, nos informa que, a partir daí, a modinha continuou influenciando compositores e gerações, ora voltando a ser quase erudito, como na modinha de Heitor Villa-Lobos (1887-1959), ora transformando-se em simples canções do repertório popular, impulsionadas, também, pelo advento do rádio. A parceria de Silvio Caldas e Orestes Barbosa, a famosa "Chão de estrelas", poderia ser um exemplo de "modinha dos anos 30":

\footnotetext{
Chão de estrelas ${ }^{4}$

Minha vida era um palco iluminado

E eu vivia vestido de dourado

Palhaço das perdidas ilusões

Cheio dos guizos falsos da alegria

Andei cantando minha fantasia

Entre as palmas febris dos corações

Meu barracão lá no morro do Salgueiro

Tinha o cantar alegre de um viveiro

Foste a sonoridade que acabou

E hoje, quando do Sol a claridade

Forra o meu barracão, sinto saudade

Da mulher, pomba-rola que voou

Nossas roupas comuns dependuradas

$\mathrm{Na}$ corda qual bandeiras agitadas

Pareciam um estranho festival

Festa dos nossos trapos coloridos

A mostrar que nos morros mal vestidos

É sempre feriado nacional.

A porta do barraco era sem trinco
}

\footnotetext{
3 Disponivel em: http://cifrantiga3.blogspot.com/2006/08/saudade-do-meu-barraco.html. Acesso em: 12 jan. 2019.

40 poeta Manuel Bandeira costumava atribuir ao verso "tu pisavas nos astros distraída" o título de "mais belo da língua portuguesa".
} Disponivel em: http://natura.di.uminho.pt/ jj/musica/html/brasil-chaoDeEstrelas.html. Acesso em: 14 fev. 2019. 
Mas a lua furando nosso zinco

Salpicava de estrelas nosso chão

E tu pisavas nos astros distraída

Sem saber que a ventura desta vida

É a cabrocha, o luar e o violão.

O poeta Manuel Bandeira e o compositor Jaime Ovalle ainda compuseram uma modinha, em 1943, no velho estilo lírico dos primórdios da história do gênero. Triste e singela no começo, sem ser excessivamente sentimental como as suas precursoras de fins do século XIX, é uma obra-prima de conjugação entre letra e música. O modo menor subitamente transforma-se em maior (verso "eu te suplico, te imploro..."), coincidindo com a repentina alegria do poeta, retornando ao menor quando repete a primeira estrofe.

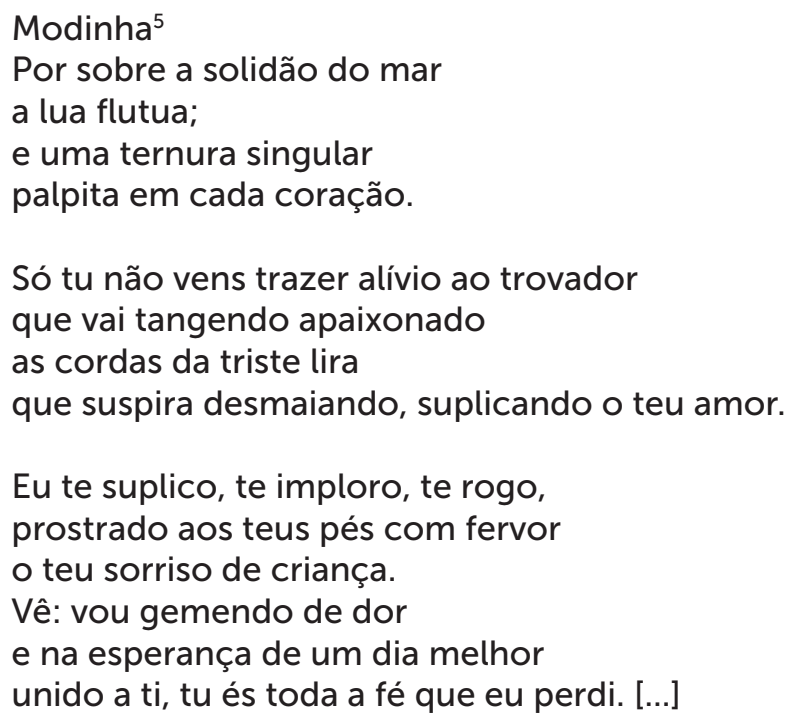

Com a febre da bossa-nova, pontua Tinhorão (1975), os compositores não deixaram de lado as antigas formas de canção de amor. Prova disso é a modinha composta por Antonio Carlos Jobim e Vinicius de Moraes, curto poema delicado, de caráter mais intimista:

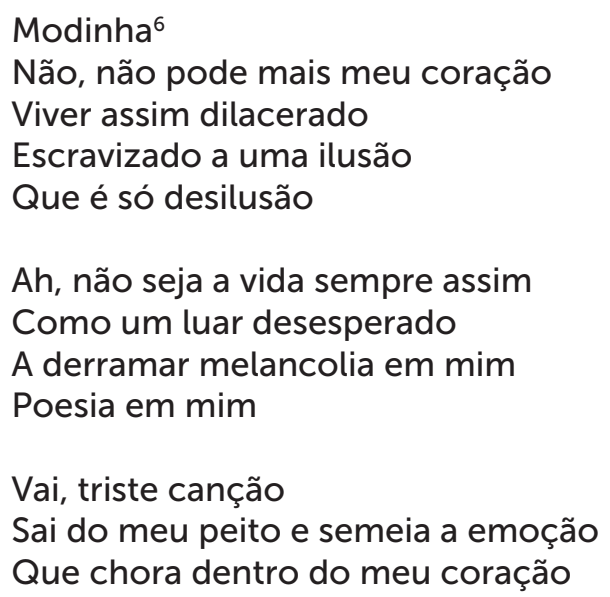

5 Disponivel em: http://www.sovacodecobra.com.br/2003/10/01/. Acesso em: 24 fev. 2019. 
Da geração posterior à de Vinicius, segundo Tinhorão (1975), encontram-se reminiscências de autêntica modinha em uma canção de Chico Buarque de Hollanda, "Até pensei", de 1967. Desse período em diante, no entanto, as inúmeras mudanças quanto à concepção de composição, o aprimoramento das técnicas de gravação e a própria transformação da sociedade levaram a canção - derivada, dentre outros estilos, da velha modinha - a tomar rumos dos mais variados, que, consequentemente, podem ter mudado sua função social.

O professor e compositor Luiz Tatit (MATHIAS, 2004), por outro lado, avalia que a tecnologia contribuirá para que a melodia cantada com acompanhamento se desenvolva de outros modos, tornando-se um estilo novo, de acordo com a contemporaneidade.

A pesquisa, portanto, continuará, lançando luz à problemática: qual o possível substituto da modinha e suas funções sociais? Qual o estilo do cancioneiro atual que parece ser similar, dentro da sociedade, ao fenômeno da modinha, ou que compositores atuam, hoje, como verdadeiros modinheiros do século XXI?

Para fins de análise, submeteu-se a modinha "Viola quebrada", a única realmente composta por Mário de Andrade e posteriormente harmonizada por Villa-Lobos em arranjo para canto e piano. Caracteristicamente dolente e sentimental, é de um lamento peculiar modinheiro, e o poema estrófico é adaptado ao drama particular do caipira, aproximando-a de uma moda de viola.

\title{
Análise
}

Viola quebrada - Modinha de Mário de Andrade, harmonizada por Villa-Lobos

\author{
Quando da brisa o açoite a frô da noite se acurvou \\ fui s'incontrá co'a maroca, meu amor \\ eu tive n'arma um choque duro \\ quando ao muro já no escuro \\ meu oiá andou buscando a cara dela e não achou \\ Minha viola gemeu \\ meu coração estremeceu \\ minha viola quebrou \\ teu coração me deixou \\ Minha maroca resorveu pra gosto seu me abandonar \\ pruquê os fadista nunca sabe trabaiá \\ isso é besteira que das frô que bria e cheira a noite inteira \\ vem dispois as fruita que dá gosto de saboreá \\ Pru causa dela eu sou rapaiz muito capaz de trabaiá \\ os dia inteiro e as noite inteira capinar \\ eu sei carpir pruquê minha'arma tá arada e loteada \\ capinada coas foiçada dessa luz do teu oiá
}




\title{
Modinha para análise poética - "Viola quebrada"
}

\begin{abstract}
A tentativa de implantação da cultura européia em extenso território, dotado de condições naturais, se não adversas, largamente estranhas à sua tradição milenar, é, nas origens da sociedade brasileira, o fato dominante e mais rico em conseqüências. Trazendo de países distantes nossas formas de convívio, nossas instituições, nossas idéias, e timbrando em manter tudo isso em ambiente muitas vezes desfavorável e hostil, somos ainda hoje uns desterrados em nossa terra. Podemos construir obras excelentes, enriquecer nossa humanidade de aspectos novos e imprevistos, elevar à perfeição o tipo de civilização que representamos: o certo é que todo o fruto de nosso trabalho ou de nossa preguiça parece participar de um sistema de evolução próprio de outro clima e de outra paisagem. (HOLANDA, 1981, p.3).
\end{abstract}

O trecho citado acima, com o qual o historiador Sérgio Buarque de Holanda abre Raízes do Brasil, sua obra capital, publicada originalmente em 1936, embora extenso, é de fundamental importância para uma análise, ainda que inicial, das características que constituem a formação da sociedade brasileira. Como disserta Mário de Andrade (1963, p.17), de forma similar: "Tendo importado a civilização cristã, correspondente a outras necessidades sociais e outros climas, a sociedade brasileira sofreu naturalmente, e por muitas partes ainda sofre, os perigos e falsificações dessa anormalidade". A contradição apresentada reside, principalmente, no seguinte fato: um país continental, de clima tropical, habitado por nativos indígenas, foi colonizado, povoado e administrado como se fosse um grande país da Europa ocidental, sem que fossem levadas em conta as suas condições particulares não só de clima, mas, especialmente, de cultura e organização social. Buarque, dando prosseguimento à sua construção de pensamento, resume a argumentação que vinha propondo: "A experiência e a tradição ensinam que toda cultura só absorve, assimila e elabora em geral os traços de outras culturas, quando estes encontram uma possibilidade de ajuste aos seus quadros de vida" (HOLANDA, 1981, p.11).

Na peça Calabar, escrita por Chico Buarque de Hollanda, compositor e cantor, filho de Sérgio, e o dramaturgo Ruy Guerra, essa temática é retomada na canção "Fado Tropical", através dos versos: "Ai, esta terra ainda vai cumprir seu ideal, ainda vai tornarse um imenso Portugal" (HOLLANDA; GUERRA, 1973, p.25).

Essa alusão nos remete, inevitavelmente, à figura do sociólogo Gilberto Freyre, considerado, pela crítica especializada, o "inventor" do Brasil. Marras (2000) disserta a respeito do autor de Casa-grande e Senzala e sua teoria da miscigenação, tentando explicar as contradições que a mistura de etnias e culturas distintas gerou na formação da sociedade brasileira. Nas suas palavras:

Fado Tropical será decerto a mais gilbertofreyreana das canções de Chico Buarque. Sabe-se que a origem do fado - dir-se-ia: gênero tipicamente português! esteve marcada pelo lundu afro-americano do Brasil colônia, que teria aportado em Lisboa quando do regresso de D. João VI. De sua vez o batuque do lundu impregnara-se do lirismo da modinha portuguesa e daí tomara o gênero próprio de canção, difundindo-se assim desde meados do século XIX pelo Brasil afora. [...] Vacilando entre um e outro lado do Atlântico, este personagem de Fado Tropical, nem bem português nem brasileiro, descreve uma saga claramente re- 
belde às coordenadas de tempo e espaço, e historicamente impossível, aliás só franqueada a heróis míticos. Como tal, ele experimenta terríveis contradições. [...] E porque o mito deve encontrar meio para elaborar suas contradições, se assim quiser firmar-se como tal, o modo como nosso herói procede à elaboração é dado pelo mecanismo de assimilação ou do sincretismo, este que Gilberto Freyre compreende ter sido o cimento da unidade étnica nacional, tendo o colonizador português papel precípuo, com sua alma miscível, com seu catolicismo absorvente aberto à integração de traços culturais estranhos, alma flexível que herdou das experiências coloniais na Ásia e na África. (MARRAS, 2000, p. 38, 39).

O que o cientista social procura esclarecer, no trecho posterior do artigo, é que ○ "fado" brasileiro, se for entendido "fado" não apenas o gênero composicional, mas também o "destino", é algo que transcende qualquer tentativa de argumentação de intelectuais, visto que o fado da nossa terra não pode ser alvo de especulação. Como ele próprio afirma: "Pois, a que estão fadados esses trópicos? Qual o destino tropical? Que sorte é esta que não se decifra? Que não se decide. Este será o nosso fado tropical" (MARRAS, 2000, p.39). A teoria de miscigenação de Gilberto Freyre pode ilustrar esse fenômeno do país sem destino, que se assemelha, em parte, à falta de caráter do brasileiro apontada por Mário de Andrade, questão que desenvolveremos logo a seguir. As três raças, negro, índio e branco, foram amalgamadas a ponto de formarem uma nação que é múltipla não só no quesito racial, mas, também, no que compete às culturas e suas distinções. O que Marras pretende mostrar é justamente que a identidade nacional, que os escritores, historiadores e sociólogos tanto almejaram descobrir e eleger como autêntica representante das características do povo, não pode ser definida isoladamente, sendo composta por várias identidades. Dessa forma, o lirismo português, por exemplo, existe paralelamente à lascívia peculiar ao Brasil, e da mesma maneira a modinha aristocrática portuguesa, oriunda da "Casa-grande", como coloca o autor do artigo, conviveu com o lundu, música proveniente da "senzala".

Essa questão tangencia, de certa forma, a obra literária máxima do Modernismo brasileiro, Macunaíma (1928), de Mário de Andrade. O anti-herói criado por ele tenta conjugar, na sua forma física e psicológica, as três raças e as diversas culturas distintas e variadas que compõem o cenário do país. Essa tentativa de conciliação de características às vezes conflitantes se apresenta, no personagem, especialmente complexa no que concerne à religião e aos costumes, bem como no domínio específico da moral, que está mais explicitado na ambiguidade do próprio subtítulo, $O$ herói sem nenhum caráter. Mas o próprio Mário, em prefácio que acabou não sendo publicado, afirma que o "herói de nossa gente" é uma busca pela expressão das diversas facetas que o homem tipicamente brasileiro possui:

O que me interessou por Macunaíma foi incontestavelmente a preocupação em que vivo de trabalhar e descobrir o que mais possa a entidade nacional dos brasileiros. Ora depois de pelejar muito verifiquei uma coisa que me parece certa: o brasileiro não tem caráter. [...] E com a palavra caráter não determino apenas uma realidade moral não, em vez entendo a entidade psíquica permanente, se manifestando por tudo, nos costumes na ação exterior no sentimento na língua na História na andadura tanto no bem como no mal. O brasileiro não tem caráter porque não possui nem civilização própria nem consciência tradicional. (ANDRADE, 1999, p. 169). 
Referimo-nos, acima, ao domínio específico da moral, pois a civilização de estrutura predominantemente europeia, que se tentou aqui implantar, não permite que o homem brasileiro viva nas condições que o país a ele propicia. Mário de Andrade, em Notas diárias (1943), dissertando sobre Macunaíma, avalia, como Sérgio Buarque, que o brasileiro incorporou as características europeias, mas que elas são hostis, e não são, absolutamente, naturais ao seu ambiente e clima.

Um tema que se relaciona com a afirmação do autor de Raízes do Brasil, de que "somos uns desterrados em nossa terra", e que é bastante recorrente na obra de Mário de Andrade, é o tema do ócio, ou, mais propriamente, da característica preguiça brasileira. Esta é natural ao homem que vive no Brasil, é inerente a ele, não só devido a fatores climáticos, como de ordem puramente cultural, em parte consequência deles. Já a mentalidade da civilização europeia, que foi importada para cá, condena esse aspecto sem ao menos considerar as diferenças que as sociedades possuem. A famosa frase de Macunaíma, repetida diversas vezes no livro homônimo, "ai, que preguiça!", consegue traduzir, em três palavras, a essência do "jeito brasileiro" de ser. Como salienta Lopez (1972, p.111): "Civilização para Mário equivale [...] a um problema de ecologia, isto é, adequação do homem ao seu meio, inclusive o clima, que no caso brasileiro é propício à preguiça". E um pouco antes explica:

Para Mário, a Arte nasce do lazer, do ócio horaciano, que pôde ser compreendido pelo Cristianismo, cuja doutrina o diferencia de preguiça = negação de luta por um ideal, pecado mortal. A civilização deveria, portanto, compreender a preguiça, dar-lhe a conotação de valor, da mesma forma que as sociedades primitivas the dão. (LOPEZ, 1972, p.110).

O próprio autor de Paulicéia desvairada, em artigo intitulado "A divina preguiça", nos conta que os nativos de nossa terra denominavam a eternidade da existência de "ócio gigantesco" (ANDRADE, 1918).

Na modinha em questão, que foi selecionada para fins de análise, encontramos essa problemática. "Viola quebrada", composta por Mário de Andrade e harmonizada por Villa-Lobos, é narrada por um caipira que, ao chegar ao local em que havia marcado um encontro amoroso, tem na alma "um choque duro", pois a "maroca", a mulher a quem devotou seu amor, não compareceu a ele. Em seguida compara a sua viola ao seu coração, pois ela gemeu e se quebrou devido à ausência da amada ao encontro, estabelecendo uma relação de causa e efeito entre o seu sentimento fervoroso e o seu amado instrumento. Na terceira estrofe, ele nos conta que a maroca o abandonou não devido a fatores que poderiam ser das mais variadas espécies, mas especificamente porque os "fadista nunca sabe trabaiá". Ou seja, sendo o caipira um fadista, um cantor que toca e canta fados, ele é considerado preguiçoso e, não podemos evitar falar, vagabundo pela namorada, e por esse motivo ela o deixou. A preguiça é, nesse contexto, tratada como algo imoral, ainda que não esteja em discussão o preconceito dirigido ao músico. Em seguida, o caipira narrador justifica o seu ócio ao comparar-se com as "frô que bria e cheira a noite inteira", da onde viriam "as fruita que dá gosto de saboreá". Olhando dessa forma, podemos arriscar que a namorada reprova algo que é inerente ao caipira, e o 
julgamento que a referida "maroca" faz dele seria como que uma conduta "importada" da civilização europeia, não sendo natural às condições em que o brasileiro está inserido. Na estrofe seguinte, o narrador afirma que é "rapaiz muito capaz de trabaiá", mas que apenas, eventualmente, o faria, "pur causa dela". Novamente, há o conflito entre a brasilidade e a cultura externa que aqui foi implantada. E continua dizendo que, por ela, capinaria "os dia inteiro e as noite inteira", e que sabe carpir porque sua alma "tá arada e loteada, capinada coas foiçada" da luz do olhar da amada. Ele se rende, finalmente, pontuando que poderá carpir e trabalhar o quanto for necessário, mas não devido à sua própria vontade, porém para cultivar o amor da mulher que ama.

\section{Conclusão}

Pode-se auferir que a modinha, estilo híbrido dos trópicos e de Portugal, representa um sincretismo cultural entre essas duas vertentes - sincretismo que só trouxe benefícios para a sua caracterização nacional, redundando no samba-canção do século XX. Melodia acompanhada especialmente por cordas dedilhadas - violão -, teve grande influência da ópera italiana, tendo sido disseminada nas casas burguesas e também popularizada com acompanhamento de piano. Sendo transformada por meio dos séculos, embora tenha simplificado a sua escrita vocal e a influência operística, preservou a temática do amor e do lamento, o modo menor, e o acompanhamento essencialmente violonístico - mesmo quando composta ou transposta para o piano.

Mário de Andrade reuniu e sistematizou as chamadas Modinhas imperiais em um único volume, em 1930, onde pode-se ver muitas das características acima - escrita de melodia acompanhada, pouco imitativa, abuso de quiálteras na mão esquerda do piano, ornamentação na linha vocal.

Para fins de análise poética, foi escolhida "Viola quebrada", a única composição de Mário de Andrade conhecida. Nela vemos condensada a crítica da estigmatização do brasileiro como indolente, preguiçoso e não afeito ao trabalho, ou seja, do ponto de vista do europeu colonizador. Terra continental de autóctones que foram desterrados e transmudados, e de negros escravizados e forçados a integrar o Cristianismo ibérico, forjou-se no Brasil uma ideia equivocada de nação - nação em que todos os elementos naturais serviram unicamente aos propósitos coloniais, e os culturais foram sistematicamente importados.

O conflito em "Viola quebrada" reside no fato de que o narrador, um caipira seresteiro, sente-se discriminado pelo seu ofício de trovador, fadista. Aqui ele parece utilizar a metáfora da natureza como o "Bom selvagem", de Rousseau (1995): não deveria ser criticado pela amada, pois, como as flores que apenas existem e mesmo assim fabricam frutos, que são alimento do homem, o fadista seria esse natural ser humano dotado de sentimentos bons e, portanto, não precisaria executar trabalhos braçais comuns. 


\section{Referências}

ANDRADE, M. de. A divina preguiça. A Gazeta, São Paulo, 28 nov. 1918.

ANDRADE, M. de. A situação etnográfica no Brasil. Jornal Síntese, Belo Horizonte, out. 1936.

ANDRADE, M. de. Notas diárias. Mensagem, Belo Horizonte, 24 jul. 1943.

ANDRADE, M. de. Música, doce música. São Paulo: Martins, 1963.

ANDRADE, M. de. Modinhas imperiais. Belo Horizonte: Itatiaia, 1980.

ANDRADE, M. de. Macunaíma. São Paulo: Klick, 1999.

ANDRADE, M. de. Pauliceia Desvairada. São Paulo: Ciranda Cultural, 2017.

ARAÚJO, M. de. A modinha e o lundu no século XVIII. São Paulo: Ricordi, 1963.

BLACKING, John. How musical is man? Washington: Washington Press, 1973.

CARLINI, A. Cantem lá que gravam cá. 1994. 467 fls. Dissertação (Mestrado) Universidade de São Paulo, São Paulo, 1994.

CASCUDO, L. da C. Dicionário de folclore brasileiro. São Paulo: Global, 2000.

CENTRO CULTURAL SÃO PAULO. "Eu sou trezentos, sou trezentos-e-cincoenta": uma "autobiografia" de Mário de Andrade. São Paulo: Prefeitura Municipal de São Paulo, 1992.

CENTRO CULTURAL SÃO PAULO. Cantos populares do Brasil: a missão de Mário de Andrade. São Paulo: Prefeitura Municipal de São Paulo, 2007

FREYRE, G. Casa-Grande e senzala. Rio de Janeiro: J. Olympio, 1983.

HOBSBAWM, E. História social do Jazz. Tradução de Ângela Noronha. São Paulo: Paz e Terra, 1996.

HOLANDA, C. B.; GUERRA, R. Calabar: o elogio da traição. São Paulo: Círculo do Livro, 1973.

HOLANDA, S. B. Raízes do Brasil. Rio de Janeiro: J. Olympio, 1981. 
IKEDA, A. T. Música política: imanência do social. 1995. 314 fls. Tese (Doutorado) Universidade de São Paulo, São Paulo, 1995.

LOPEZ, T. P. A. Mário de Andrade: ramais e caminho. São Paulo: Duas Cidades, 1972.

KIEFER, B. A modinha e o lundu: duas raízes da música popular brasileira. Porto Alegre: Movimento, 1986.

MARRAS, S. O fado tropical de Gilberto Freyre. Cult, São Paulo, mar. 2000.

MATHIAS, A. Fina estampa. Folha de S.Paulo, São Paulo, 29 ago. 2004. Caderno Mais.

MENDES, A.; RONCARI, L.; MARANHÃO, R. Brasil história: texto e consulta. Vol. 2: Império. São Paulo: Brasiliense, 1983.

PINTO, Tiago de Oliveira. Questões de antropologia sonora. Revista de Antropologia, São Paulo, v. 44, n. 1, p. 221-86, 2001.

ROUSSEAU, J. J. Emílio ou Da educação. Tradução de Sergio Milliet. Rio de Janeiro: Bertrand Brasil, 1995.

SANCHES, P. A. Era uma vez uma canção. Folha de Paulo, São Paulo, 29 ago. 2004. Caderno Mais.

SILVA, L. N. P. Mário universal paulista: algumas polaridades. São Paulo: Secretaria Municipal de Cultura, 1997.

TINHORÃO, J. R. Pequena história da música popular. Petrópolis: Vozes, 1975.

TONI, F. C. A música popular brasileira na vitrola de Mário de Andrade. São Paulo: Senac, 2003. 